\title{
An Experimental and Numerical Evaluation of Seal Strictness on Ball Bearing Performance
}

\author{
Zafer Ozdemir (iD) Osman Selim Turkbas ${ }^{(D)}$ Kaan Sarigoz (D) \\ Gazi University, Department of Mechanical Engineering, Ankara, Turkey
}

A B S T R AC T
ubber-based ball bearing seals are widely used in the bearing industry. These seals
affect the performance of the ball bearings and endurance life as well. Effect of rol-
ling bearing seal strictness value on bearing performance was investigated experimentally
and numerically in this study. Four different seal strictness rolling bearing samples were
manufactured for the tests. The bearing seal strictness which is used in tests are given res-
pectively; $200 \mu \mathrm{m}, 160 \mu \mathrm{m}, 105 \mu \mathrm{m}, 45 \mu \mathrm{m}$ and contactless. First; friction torque test was
performed without loading and bearings were rotated at $3000 \mathrm{rpm}$ for one hour. Tempera-
ture values and friction generation in bearings against rotation were measured throughout
the tests. Second; temperature tests have been carried out; roll bearings were rotated at
$6000 \mathrm{rpm}$ for one hour and $2000 \mathrm{~N}$ radial load was applied to samples. 5 samples for each
test have been used. The contact reaction force between the region of inner ring and rubber
seal inner lip was modeled by means of the finite element method and designed in ANSYS
Workbench. ANSYS results and friction moment test results have been evaluated and com-
pared. It is observed that as the strictness increases, the friction force and temperature
increase, but this affects the life cycle of ball bearing negatively. It has been seen that the
numeric results are consistent with the test results.

\author{
Article History: \\ Received: 2021/03/03 \\ Accepted: 2021/08/11 \\ Online: 2021/og/29
}

Correspondence to: Zafer Özdemir e-mails: krebnatlazafer@gmail.com, ozdemirzafer@yahoo.com;

\section{Keywords:}

Ball bearing; Rubber seal; Friction torque; Strictness; Nitrile based rubbers (NBR); Finite element analysis; Ansys

\section{INTRODUCTION}

$\mathrm{T}$ he basic working principle of a ball bearing is to reduce the friction force to a minimum and to make load transfer between two relative rotating mechanisms. The ball bearings are used among a variety of mechanisms such as shaft, axis, pumps, heavy load machines, wind turbines, and machine tools [1].

The friction force produced by ball bearings determines the heat amount produced. Friction force arises from the loads applied to ball-bearing, type and size of ball-bearing, operating cycle, lubricant properties. The total reaction force against the rotation force inside ballbearing includes sliding and rolling friction force at contact areas, the friction force between rolling elements and rolling paths, the friction force between rolling elements and the cage. Friction occurs because of lubricant movements and contact covers [2].

A ball bearing seal has 2 basic tasks; the lubricant in and keeping contaminates out of the bearing system. This separation must be accomplished between surfaces in relative motion, usually a shaft or bearing inner ring and a housing [3].

\section{LITERATURE REVIEW}

Considerable studies have been made on the rolling bearing, cage and seal strictness relation by now. Some of the notable ones have been discussed below.

T.Sada and his colleagues examined friction loss reduction of ball bearings [4]. Ł.Gorycki and his colleagues analyzed the impact of the cage type on the frictional moment of ball bearings and showed that the type of cage used in ball bearings has a significant impact on the frictional moment [5]. B.Choe and his colleagues investigated the dynamic behavior of ball bearing cage (polytetrafluoroethylene (PTFE) cages are used as solid lubricants in such environments) in cryogenic environments and suggested (PTFE) cages [6]. Y.Cui and his colleagues investigated the vibration effect analysis of ball dynamic unbalance on the cage of high-speed cylindrical ball bearing and concluded that the increase of the radial load of the bearing, to a certain extent, can reduce the vibration of cage considering the ball dynamic unbalance [7]. Z.Yang and his colleagues presented 


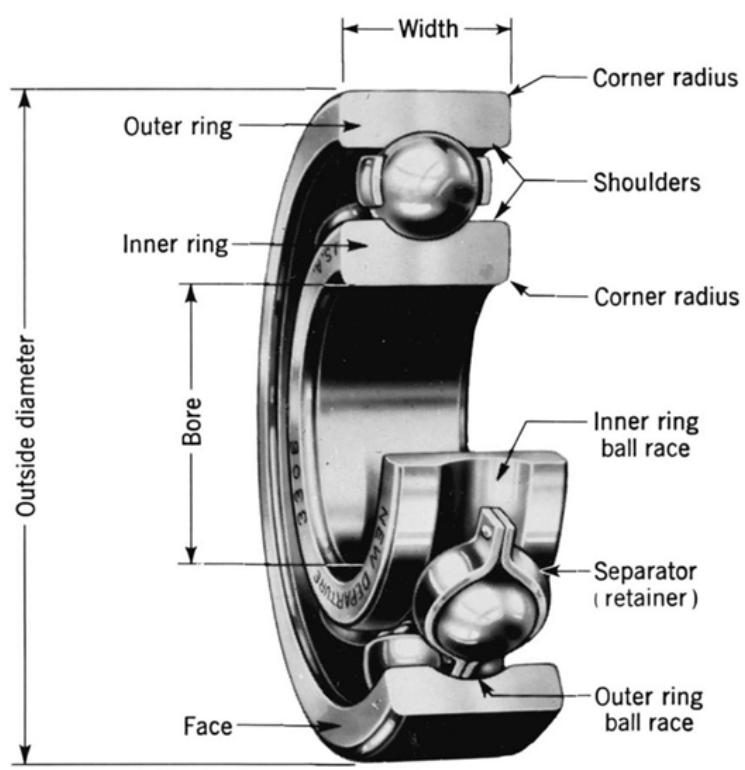

Figure 1. Nomenclature of a ball bearing. [1]

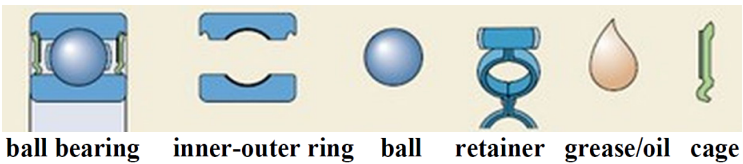

Figure 2. Components of a ball bearing [2]

a five degree-of-freedom (5-DOF) quasi-dynamic model to analyze the relationship between the cage clearance and heating characteristics. The results show that there is a critical value for both the guide and pocket hole clearance and that the heating is obviously decreased and gradually stabilizes when the clearance exceeds a critical value [8]. M.Takimoto and his colleagues introduced the development of automotive wheel bearing seals (Muddy-water resistant seal, low temperature environment seal and super low-torque seal) [9].

As the literature has been gone through, it has been seen that there is not adequate research on the seal strictness versus ball bearing performance and FEA analyze of seal strictness. This makes this study an original one in the ball bearing performance in terms of seal strictness and FEA-ANSYS field.

As friction force increases, ball bearing life decreases [4]. Theoretically, we have 2 main equations to calculate the friction force [10]. One of them is the Palmgren method [11]. According to this method, the friction force is calculated below;

$$
\begin{aligned}
& M=M_{0}+M_{1} \text { if } v \times n \geq 2000 \text { then; } \\
& M_{0}=10^{-7} \cdot f_{0}(v \times n)^{2 / 3} \cdot d m^{3} \text { if } v \times n<2000 \text { then } \\
& M_{0}=1,6 \cdot 10^{-5} \cdot f_{0} \cdot d m^{3}
\end{aligned}
$$

$$
\begin{aligned}
& M_{1}=f_{1} \cdot P_{1} \cdot d m \\
& f_{1}=z\left(F_{s} / C_{s}\right) y
\end{aligned}
$$

\begin{tabular}{|c|c|c|c|}
\hline Rolling BearType & $\begin{array}{c}\text { Nominal Contact Angle } \\
{[\circ]}\end{array}$ & $z$ & $y$ \\
\hline Deep Groove Ball Bearing & 0 & $\begin{array}{l}0,0004^{-} \\
0,0006\end{array}$ & 0,55 \\
\hline Angular Contact Ball Bearing & $30-40$ & 0,001 & 0,33 \\
\hline Axial Contact Ball Bearing & 90 & 0,0008 & 0,33 \\
\hline Self-Aligning Ball Bearing & 10 & 0,0003 & 0,40 \\
\hline
\end{tabular}

$\mathrm{F}_{\mathrm{s}}$ equivalent statical load and $\mathrm{C}_{\mathrm{s}}$ are statically load number, $\mathrm{z}$ and $\mathrm{y}$ values are presented at table 1. [6].

Table 1. Coefficients according to the bearing types to calculate f1
M: Total friction moment (Nmm.)
$\mathrm{M}_{0}$ : Oiling friction moment (Nmm.)
$\mathrm{M}_{1}$ : Load friction moment $(\mathrm{Nmm}$.
$\mathrm{n}: \quad$ Cycle (rpm)
v: Kinematic viscosity of oil $\left(\mathrm{m}^{2} / \mathrm{s}\right)$
$\mathrm{f}_{0}$ : Ball bearing coefficient
$\mathrm{dm}$ : Ball bearing mean diameter $(\mathrm{mm}$.)
$\mathrm{f}_{1}$ : Coefficient according to the bearing type and load $\mathrm{P}_{1}: \operatorname{Load}(\mathrm{N})$

Friction moment calculation according to the SKF Company [11];

$M=M_{r r}+M_{s l}+M_{\text {seal }}+M_{\text {drag }}$

M: Total friction moment (Nmm.)

$\mathrm{M}_{\mathrm{r}}$ : Radial friction moment (Nmm.)

$\mathrm{M}_{\mathrm{sl}}$ : Sliding friction moment (Nmm.)

$\mathrm{M}_{\text {seal }}$ : Seal friction moment (Nmm.)

$\mathrm{M}_{\text {drag }}$ : Dragging friction moment (Nmm.) (oil, grease, and reaction against force and rolling)

Mathematical equations consider some variables affecting friction moment; however, cage design, cover strictness, bearing rolling ways, radius values, rolling way roughness affect friction moment. Therefore, it is necessary to conduct experimental studies to ensure the best performance of ball bearings life cycle.

Ball bearings are used with rubber-based seals, ironplate based seals and without seals. No maintenance is required for rubber-based and iron-plate based seals for a lifetime $[3,12]$.
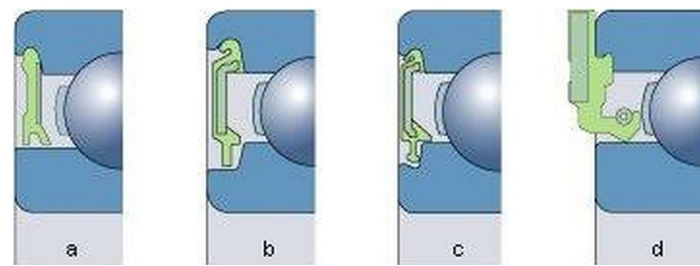

Figure 3. Some rubber-based seals design comprehensively used in SKF Company 


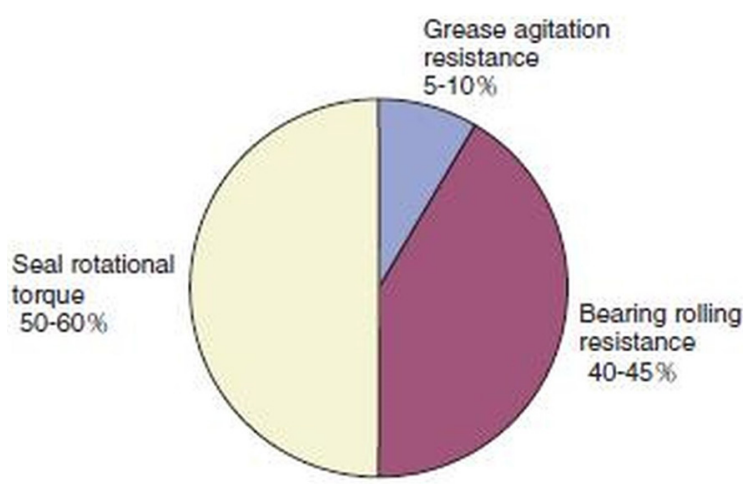

Figure 4. The effect of friction torque at a ball bearing [11]

There are some types of rubber-based seals used in ball bearings. Below are some of them presented comprehensively used in the SKF Company [11].

As seen in Fig 4, most of the friction torque arises from the seal cage rotational torque. The $\% 50-60$ of friction in ball bearing is caused approximately from seal rotational torque, \%40-45 from bearing rolling resistance and \%5-10 from grease agitation resistance [3,11]. According to the data, the great part of the friction is caused from seals.So, the design of seal is an important parameter for ball bearing manufacture.

At higher cycles; iron plate-based seals and contact-free rubber-based seals have advantages on performance. However, it is better to use rubber-based seals if tightness is desired.

\section{MATERIALS AND METHOD}

\section{Experimental Study}

Reaction and performance of rubber-based seals having different strictness values have been examined using the experimental setup as seen in Fig 5. Radial 6008 2RSR ball bearing is used in tests (Fig 6).

The tests aim to investigate and determine the effect of seal strictness on the performance of bearing and to measure the bearing life theoretically. Special fabricated rubberbased seals at different strictness have been used in 6008 2RSR ball bearings.

Two different types of tests have been conducted; 1) friction moment-time, 2) temperature-time tests.

The outer ring of the ball bearing was fixed to the outer side of the shaft with a screw, and the inner ring was mounted to the shaft. Screw transmits the force to the load cell. The friction moment could be calculated by the load cell via this connection as seen in figure 5 . X is $20 \mathrm{~cm}(200 \mathrm{~mm}$.)

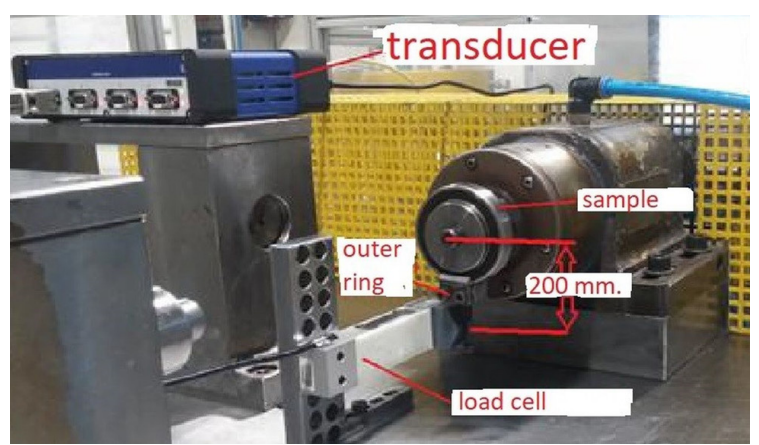

Figure 5. Experimental setup
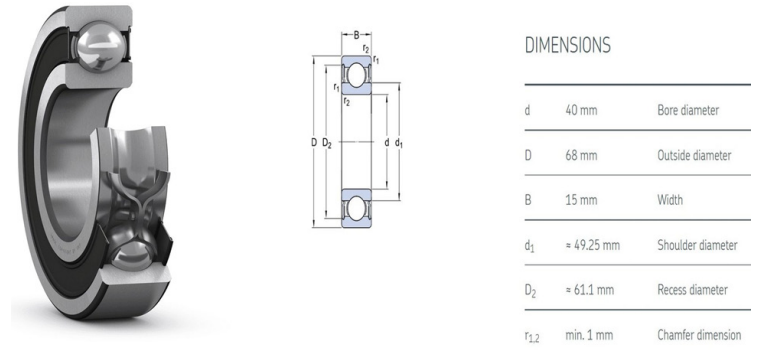

Figure 6. Radial 6008 2RSR ball bearing and dimensions used in tests [11]

$$
\begin{aligned}
& M=F . X \\
& \text { M: Friction moment (Nm.) } \\
& \text { F: Force (N.) } \\
& \text { X: distance (m.) }
\end{aligned}
$$

Before tests; 1) Bolt and nut tightness of the setup has been controlled 2) Radial gap is not allowed in the samples and 3) Roller bearing samples are manually rotated to control the setup.

\section{Preparation of Rubber-Based Seals (RSR-Rubber Seal Radial) Having Different Strictness}

Seal strictness is the measure of the stress of this seal to the inner ring of the ball bearing to provide. oil tightness. As the strictness value increase, the tightness increase [12] and [13].

NBR (Nitrile Based Rubbers) have been used in our experimental studies. NBR are copolymers of butadiene and acrylonitrile. The term has also been applied to copolymers of other dienes and/or nitriles. Acrylonitrile content may range from 18-50\%. Increasing acrylonitrile content leads to higher hardness, strength, abrasion resistance, heat resistance, and oil/fuel resistance and lower resilience and low-temperature flexibility [14]. The enduring temperature range is between $-40^{\circ} \mathrm{C}$ and $110^{\circ} \mathrm{C}$ [14].

Half section view of ball bearing used in experiments is shown in Fig. 7. As seen in detail-A, it could be seen what a seal strictness is. It is easier to adjust the strictness at radial ball bearings because machining tolerance is lower since the 


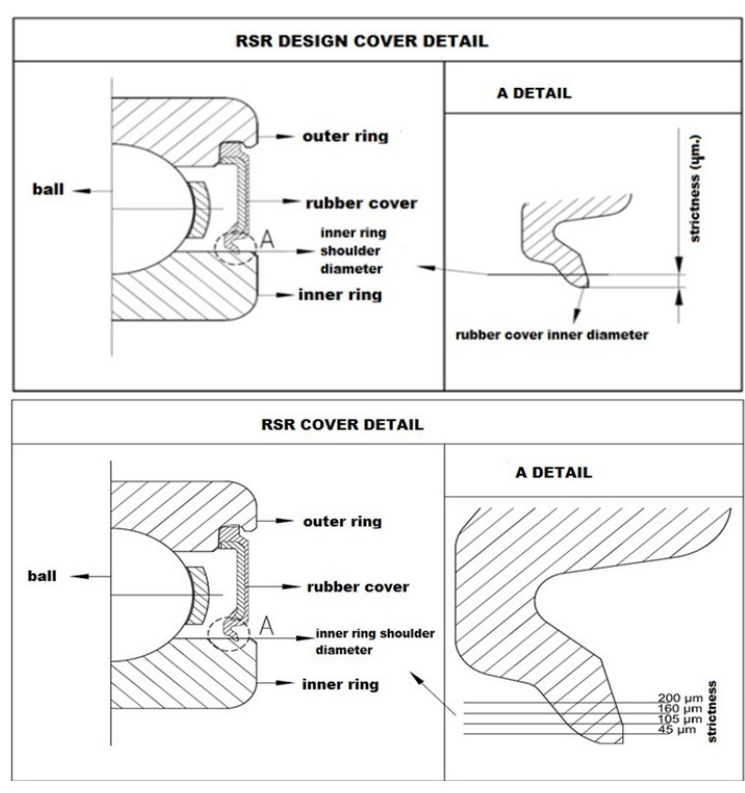

Figure 7. The strictness of seals and the values used in tests of Radial 6008 2RSR ball bearing

inner ring shoulder was machined at a grinding machine, not at a lathe. 8.)

The sensitivity of the measuring device is $0,05 \mu \mathrm{m}$. (Fig.

The measurements have been conducted by optical and laser measuring method; optical camera laser measurement device (Fig. 9.) scale resolution is $0,1 \mu \mathrm{m}$.

Seal strictness design calculation is presented below:

Seal Strictness $[\mu \mathrm{m}]=$ Inner ring shoulder diameterRadial seal inner diameter (8)

Inner ring shoulder diameter: $100 \mathrm{~mm}$.

Radial seal inner diameter: $99,8 \mathrm{~mm}$.

Seal strictness: $100-99,8=200 \mu \mathrm{m}$

Seal strictness in radius: $100 \mu \mathrm{m}$ (Seal strictness worked

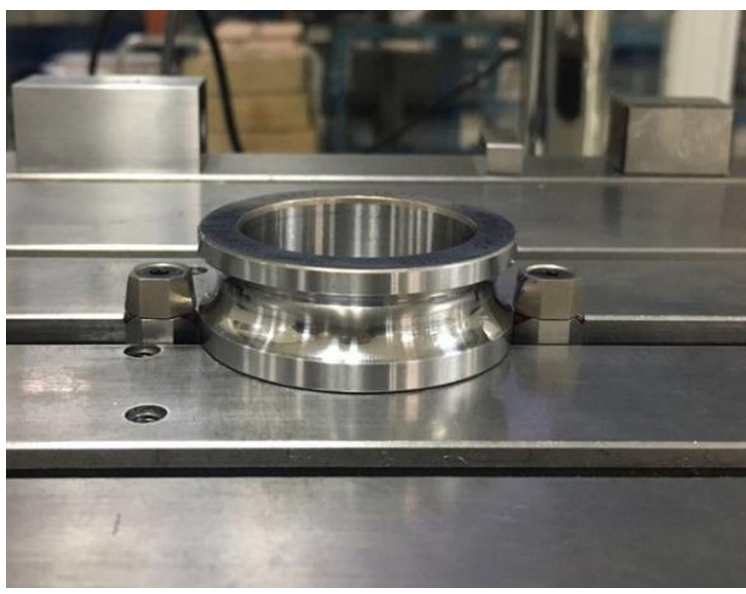

Figure 8. Measuring the diameter of the inner ring

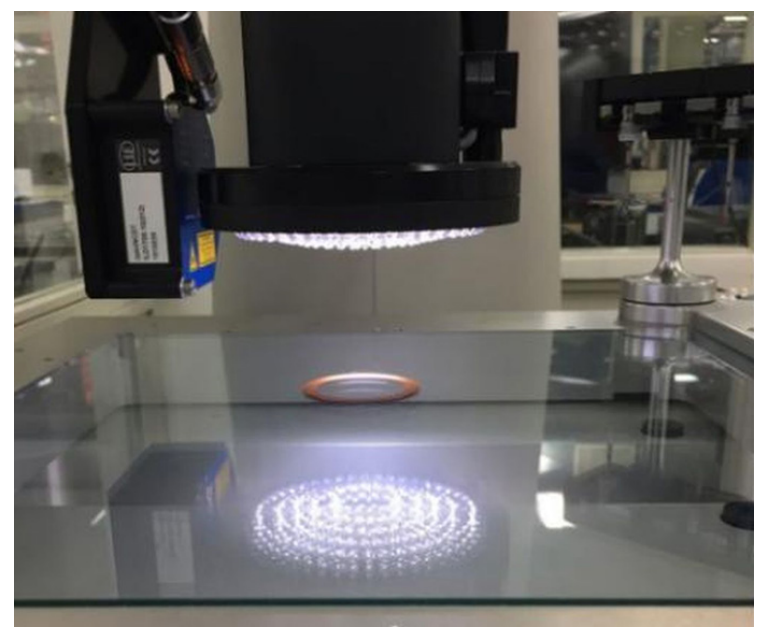

Figure 9. Measuring the inner diameter of the rubber-based seal

out in this study are based on mostly mentioned in real-life usage of ball bearings.) Seal strictness values of inner ring shoulder diameter and radial seal inner diameter for all test samples of ball bearings were measured exactly \%100 with $\pm 10 \mu \mathrm{m}$ tolerance. Each seal strictness group has 5 samples.

\begin{tabular}{|c|c|c|c|c|c|}
\hline Sample Number & $200 \mu \mathrm{m}$ & $160 \mu \mathrm{m}$ & $105 \mu \mathrm{m}$ & $45 \mu \mathrm{m}$ & Contactless \\
\hline 1 & 201,7 & 161,8 & 113,2 & 42,7 & - \\
\hline 2 & 203,7 & 156,8 & 102,7 & 43,1 & - \\
\hline 3 & 208 & 159,2 & 103,7 & 38,3 & - \\
\hline 4 & 197,8 & 165,4 & 103,1 & 40,1 & - \\
\hline 5 & 200,3 & 158,7 & 115,1 & 43,5 & - \\
\hline Mean Value $[\mu m]$ & 202,3 & 160,4 & 107,6 & 41,5 & - \\
\hline
\end{tabular}

The values indicated in table 2 are the seal strictness values of specially fabricated rubber seal values. 5 different groups have been fabricated and the mean values are taken as respectively 200, 160, 105 and $45 \mu \mathrm{m}$ for calculation. After the heat treatment process, rolling bearings' last fabrication process has been carried out at and the rubber seals are mounted then. A very sensitive process has been carried out as seen in Fig. 8.and 9.

\section{Test Conditions}

Specifications of ball bearings used in tests are detailed in table 3 below:

Table 3. Specifications of ball bearings

\begin{tabular}{cc}
\hline Rolling Bearing Used & $60082 R S R$ \\
\hline CoverType & Radial Sealing Element \\
Rubber/Seal Cover Material & NBR \\
Quantity of Grease Oil & $\%$ zo of Rolling Bearing Inner Volume \\
Radial Gap & $C_{3}$ \\
Cage Type & $\mathrm{J}$ \\
& $200 \mu \mathrm{m}$ \\
Rolling Bearing Cover Strictness & $160 \mu \mathrm{m}$ \\
& $105 \mu \mathrm{m}$ \\
& $45 \mathrm{~m}$ \\
\end{tabular}


In temperature test; The aim is to investigate the effect of temperature on the seal strictness at $6000 \mathrm{rpm}$ and 2000 $\mathrm{N}$ radial load.

The tests have been conducted according to the ASTM G182 - 13 (2018) "Standard Test Method for Determination of the Breakaway Friction Characteristics of Rolling Element Bearings" [15] and DIN 51819-1 2016 Edition, December 2016 "Testing of lubricants - Mechanical-dynamic testing in the roller bearing test apparatus FE8 - Part 1: General working principles" [16].

Table 4. Test Conditions

\begin{tabular}{ccc}
\hline Test Conditions & Friction Moment Test & Temperature Test \\
\hline Cycle (RPM) & 3000 & 6000 \\
Radial Force (N.) & - & 2000 \\
Time (min.) & 60 & 60 \\
Inner Ring & rotating & rotating \\
Outer Ring & fixed & fixed \\
Data Collection & $1 \mathrm{~Hz}$. & $60 \mathrm{~Hz}$. \\
\hline
\end{tabular}

\section{EXPERIMENTAL RESULTS}

The results that have been given are the mean values of the collected data through the tests.

\section{Friction Moment Test}

\section{Friction Moment-Time}

Friction moment versus time values of $200 \mu \mathrm{m}$. seal strictness samples have been observed as seen in Fig. 10. Starting torque is greater, but as the steady state occurs the torque decreases. Approximately, at the 300th second, the steady state begins. The mean friction value has been observed between 0,115 Nm.(number 4 sample) and 0,156 Nm. (number 2 sample).

Friction moment versus time values of $160 \mu \mathrm{m}$. seal strictness samples have been observed in Fig. 11. Starting torque is greater, but approximately, at the 300th second, the steady state begins. The mean friction value has been observed between 0,093 Nm. (number 2 sample) and 0,118 Nm. (number 4 sample).

Friction moment versus time values of $105 \mu \mathrm{m}$. seal strictness samples have been observed in Fig. 12. Starting torque is greater, but approximately, at the 600th second, the steady state begins. The mean friction value has been observed between 0,060 Nm. (number 4 sample) and 0,088 Nm. (number 1 sample).

Friction moment versus time values of $45 \mu \mathrm{m}$. seal strictness samples have been observed in Fig. 13. Starting torque is greater, but approximately, at the 300th second, the steady state begins. The mean friction value has been obser-

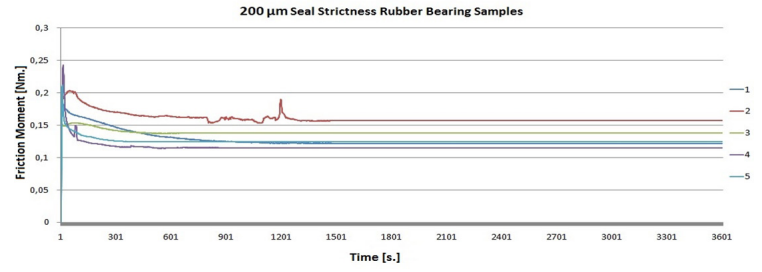

Figure 10. Friction moment values of $200 \mu \mathrm{m}$. seal strictness according to time (5 samples)

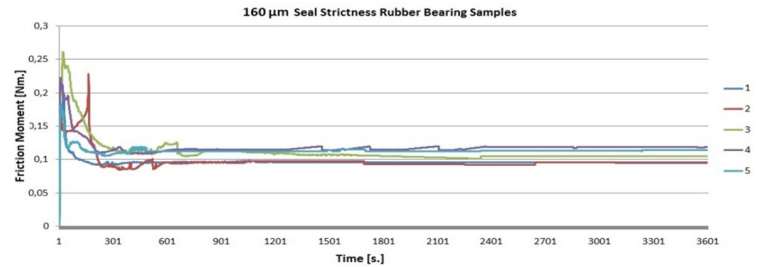

Figure 11. Friction moment values of $160 \mu \mathrm{m}$. seal strictness according to time (5 samples)

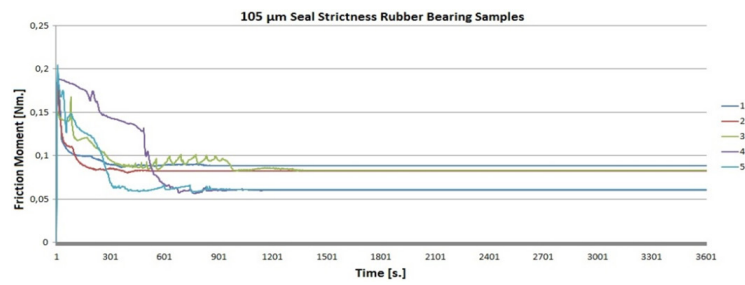

Figure 12. Friction moment values of $105 \mu \mathrm{m}$. seal strictness according to time (5 samples)

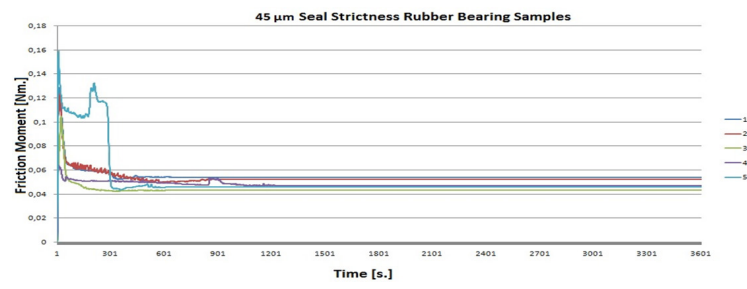

Figure 13. Friction moment values of $45 \mu \mathrm{m}$. seal strictness according to time (5 samples)

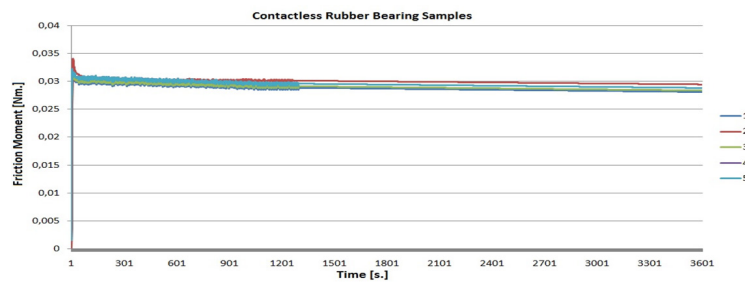

Figure 14. Friction moment values of contactless rubber bearings according to time (5 samples)

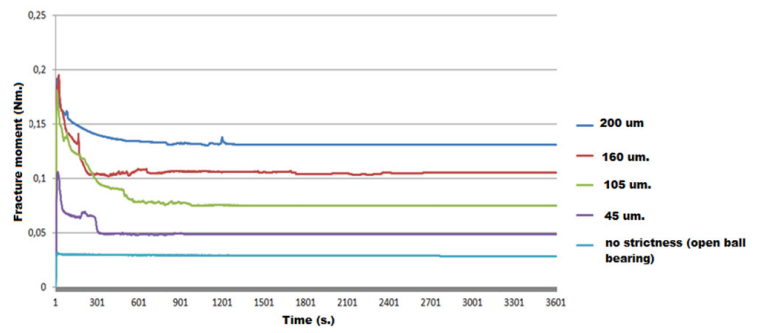

Figure 15. Mean friction values of different seal strictness according to time 


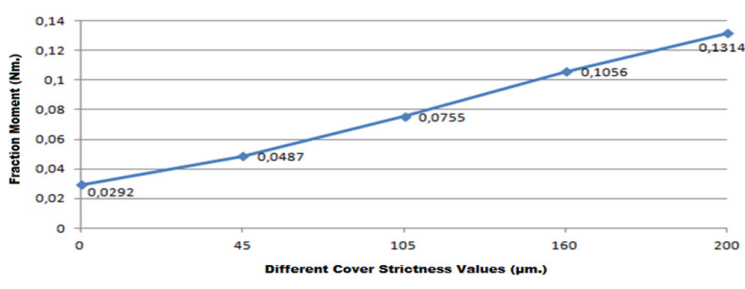

Figure 16. Different seal strictness; mean friction values

ved between 0,043 Nm. (number 3 sample) and 0,054 Nm. (number 1 sample).

A more stable graphic is observed for the contactless rubber bearings as seen in Fig. 14. The mean friction value has been observed between 0,0282 Nm. (number 1 sample) and 0,0295 Nm. (number 2 sample).

Mean friction moment results have been shown in Fig. 16. As the seal strictness increases, friction moment increases linearly. Ball bearing has been tested without any load, so the effect of strictness could be determined obviously. The last $50 \mathrm{~min}$. friction moment values have been considered, not at first $10 \mathrm{~min}$. values. Mean friction moment values have been given according to different seal strictness at table 5 .

Table 5. Friction moment results collected of different seal strictness

\begin{tabular}{cccc}
\hline & \multicolumn{3}{c}{ Mean friction moment values [Nm] } \\
\hline $\begin{array}{c}\text { Ball bearings according } \\
\text { to the seal strictness }\end{array}$ & 1 hour & First 10 minutes & Last 50 minutes \\
$200 \mu \mathrm{m}$ & 0,1334 & 0,1435 & 0,1314 \\
$160 \mu \mathrm{m}$ & 0,1076 & 0,1176 & 0,1056 \\
$105 \mu \mathrm{m}$ & 0,0806 & 0,1059 & 0,0755 \\
$45 \mu \mathrm{m}$ & 0,0504 & 0,0591 & 0,0487 \\
$0 \mu \mathrm{m}$ & 0,0293 & 0,0299 & 0,0292 \\
\hline
\end{tabular}

\section{Temperature Test}

Temperature change according to time has been observed at temperature tests. The specifications of the rolling bearing used in tests are shown in table 2 . The same samples are used as in friction tests. 2000 N. Radial load is applied and $6000 \mathrm{rpm}$ cycle has been carried out as shown in table 6.

Table 6. Temperature Pre-Test Values

\begin{tabular}{cc}
\hline Cycle (rpm.) & 6000 \\
\hline Radial Load (N.) & 2000 \\
Test Duration (min.) & 60 \\
Inner Ring & Rotating \\
Outer Ring & Fixed \\
Temperature Data Collection Frequency (Hz.) & $1 / 30$ \\
\hline
\end{tabular}

The test aims to observe and evaluate the effect of seal strictness values differences. According to the obtained values, the life cycle of ball bearings (rolling bearings) and real life cycle of ball bearings will be calculated according to the ISO 281:2007 (Rolling Bearings - Dynamic Load Ratings and Rating Life) [17].

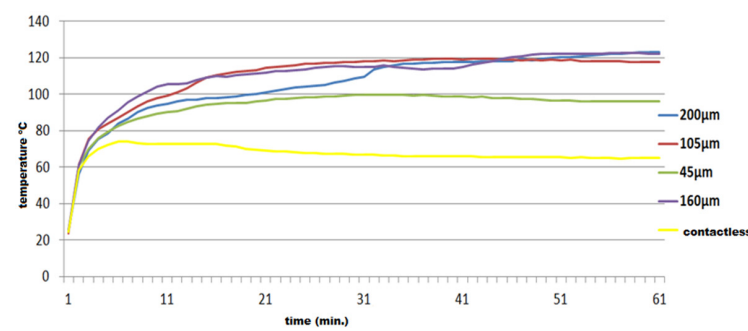

Figure 17. Different seal strictness; time versus temperature

The ambient temperature is $20^{\circ} \mathrm{C}$. Measurement frequency is $1 / 30 \mathrm{~Hz}$ and the total test time is $60 \mathrm{~min}$. A sensitive probe touching to the outer ring of rolling bearings measures the temperature.

Mean temperature values according to time have been shown in Fig. 17. As the seal strictness increases, friction moment increases and henceforth temperature increases; but temperature values become steady almost after $12 \mathrm{mi}$ nutes. $200 \mu \mathrm{m}, 160 \mu \mathrm{m}$ and $105 \mu \mathrm{m}$ seal strictness ball bearings temperature values are almost the same after a steady state after 41 minutes.

The temperature test results have been shown in table 7. As seen in Table 7, we need 30 minutes to be sure and obtain accurate data. After 30 minutes; the effect of strictness versus temperature could be seen obviously.

Table 7. Temperature test results.

\begin{tabular}{ccc}
\hline $\begin{array}{c}\text { Different seal } \\
\text { strictness }\end{array}$ & $\begin{array}{c}\text { Mean temperature values } \\
\text { Last } 30 \text { minutes }\left({ }^{\circ} \mathrm{C}\right)\end{array}$ & $\begin{array}{c}\text { Maximum temperature } \\
\text { values }\left({ }^{\circ} \mathrm{C}\right)\end{array}$ \\
\hline $200 \mu \mathrm{m}$ & 118,9 & 150 \\
$160 \mu \mathrm{m}$ & 118,9 & 145 \\
$105 \mu \mathrm{m}$ & 118,6 & 132,5 \\
$45 \mu \mathrm{m}$ & 97,8 & 104 \\
$0 \mu \mathrm{m}$ & 65,7 & 67 \\
\hline
\end{tabular}

Temperature (max. and mean values) versus seal strictness values have been observed as seen in Fig. 18. Temperature does not change at $105 \mu \mathrm{m}, 160 \mu \mathrm{m}$ and $200 \mu \mathrm{m}$ strictness after the steady-state begins. The mean temperature value is approximately $119^{\circ} \mathrm{C}$. The contactless rolling bearing is $65,7^{\circ} \mathrm{C}$ and $45 \mu \mathrm{m}$ strictness is $97,8^{\circ} \mathrm{C}$.

According to the temperature test results having 6000 rpm and 2000 N. load, after a value bigger than $105 \mu \mathrm{m}$, temperatures are the same. So it can be concluded that smaller seal strictness values than $105 \mu \mathrm{m}$ should be preferred for fewer temperature degrees.

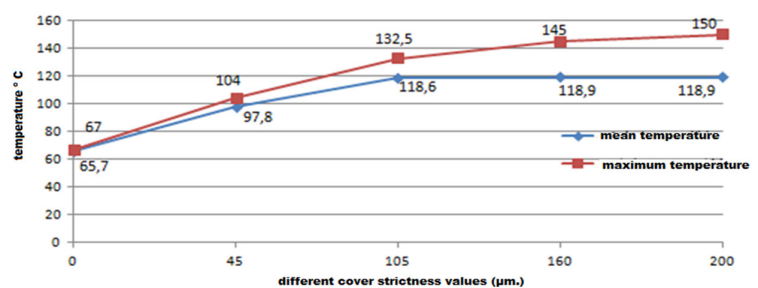

Figure 18. Seal strictness; mean and max. temperatures 
Table 8. Temperature Test Values

\begin{tabular}{ccccc}
\hline $\begin{array}{c}\text { Seal } \\
\text { Strictness }\end{array}$ & $\begin{array}{c}\text { Mean } \\
\text { Temperature, } \\
\text { Last 30.min. } \\
\left({ }^{\circ} \mathrm{C}\right)\end{array}$ & $\begin{array}{c}\text { The ratio } \\
\text { of mean } \\
\text { temperature } \\
\text { to a minimum } \\
\text { temperature }\end{array}$ & $\begin{array}{c}\text { Maximum } \\
\text { Rolling } \\
\text { Bearing } \\
\text { Temperature } \\
\left({ }^{\circ} \mathrm{C}\right)\end{array}$ & $\begin{array}{c}\text { The ratio } \\
\text { of mean } \\
\text { temperature } \\
\text { to maximum } \\
\text { temperature }\end{array}$ \\
\hline $200 \mu \mathrm{m}$ & 118,9 & $118,9 / 65,7=1,81$ & 150 & $150 / 67=2,23$ \\
$160 \mu \mathrm{m}$ & 118,9 & $118,9 / 65,7=1,81$ & 145 & $145 / 67=2,16$ \\
$105 \mu \mathrm{m}$ & 118,6 & $118,6 / 65,7=1,80$ & 132,5 & $132,5 / 67=1,97$ \\
$45 \mu \mathrm{m}$ & 97,8 & $97,8 / 65,7=1,48$ & 104 & $104 / 67=1,55$ \\
contactless & 65,7 & 1 & 67 & 1 \\
\hline
\end{tabular}

Mean and maximum temperature values are shown in table 8.

\section{Calculating of Ball Bearing Life Theoretically According to the Temperature Test Results}

The life cycle of ball bearings (rolling bearings) is standardized according to the ISO 281:2007 (Rolling Bearings - Dynamic Load Ratings and Rating Life) [17].

$$
L_{10}=\left(C_{r} / P_{r}\right)^{3}
$$

Here in this equation;

$\mathrm{C}_{\mathrm{r}}$ : Basic Dynamic Radial Load Rating [Newton]

$\mathrm{P}_{\mathrm{r}}$ : Dynamic Equivalent Radial Load [Newton]

$\mathrm{L}_{10}$ : basic life cycle [million cycle]. Here, the number 10 is a definition considered statistically.

\section{Developed a Life Cycle}

Below is the equation that gives this formula of the developed rolling bear life cycle [17].

$\mathrm{L}_{\mathrm{nm}}=\mathrm{a}_{1} \cdot \mathrm{a}_{1 \mathrm{so}} \cdot \mathrm{L}_{10}$

$\mathrm{L}_{\mathrm{nm}}$ : Developed a life cycle.

$a_{1}$ : Life modification factor for reliability

$\mathrm{a}_{150}$ : Life modification quotient is as given in references [17] and [18].

The life cycle results calculated at MESYS software [19] (figure 19). According to the tests, the results are presented in Fig. 18 and 19.

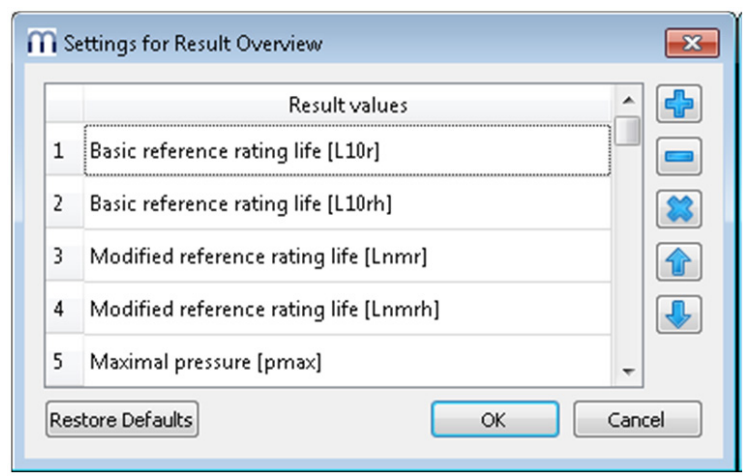

Figure 19. The computing of the life cycle by MESYS software

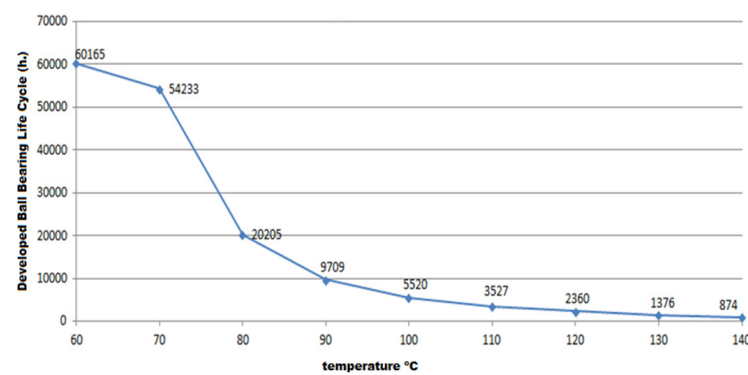

Figure 20. 6008 ball bearing developed life cycle versus temperature computed by MESYS software [19]

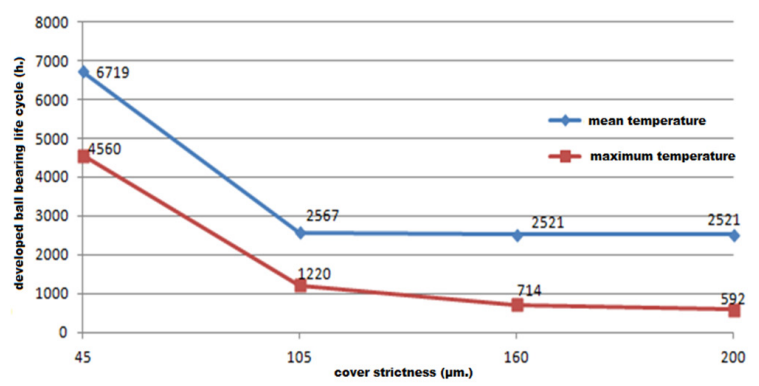

Figure 21. 6008 ball bearing developed life cycle versus seal strictness based on mean and max. temperatures computed by MESYS software [19].

The life cycle of ball bearings according to the temperature and seal strictness values are presented in Fig. 20 and 21. As strictness increases, the life cycle decreases. The most dramatic drop in the life cycle is between $45 \mu \mathrm{m}$ and $105 \mu \mathrm{m}$. Between $105 \mu \mathrm{m}$ and $200 \mu \mathrm{m}$, a slight decrease in the life cycle has been observed. This is because temperature degrees also slightly decrease between $105 \mu \mathrm{m}$ and $200 \mu \mathrm{m}$ as seen in Fig. 21.

Table 9. Developed life cycle versus seal strictness based on mean and max. temperatures

\begin{tabular}{|c|c|c|c|c|}
\hline $\begin{array}{c}\text { Seal } \\
\text { Strictness }\end{array}$ & $\begin{array}{c}\text { Mean } \\
\text { Temperature, } \\
\text { Last 3o.min. } \\
\left({ }^{\circ} \mathrm{C}\right)\end{array}$ & $\begin{array}{c}6008 \text { ball } \\
\text { bearing } \\
\text { developed life } \\
\text { cycle (h.) }\end{array}$ & $\begin{array}{c}\text { Maximum } \\
\text { Rolling } \\
\text { Bearing } \\
\text { Temperature } \\
\left({ }^{\circ} \mathrm{C}\right) \\
\end{array}$ & $\begin{array}{c}6008 \text { ball } \\
\text { bearing } \\
\text { developed life } \\
\text { cycle (h.) }\end{array}$ \\
\hline $200 \mu \mathrm{m}$ & 118,9 & 2521 & 150 & 592 \\
\hline $160 \mu \mathrm{m}$ & 118,9 & 2521 & 145 & 714 \\
\hline $105 \mu \mathrm{m}$ & 118,6 & 2567 & 132,5 & 1220 \\
\hline $45 \mu m$ & 97,8 & 6719 & 104 & 4560 \\
\hline contactless & 65,7 & 60165 & 67 & 60165 \\
\hline
\end{tabular}

The developed life cycles according to the seal strictness values are given in table 9. It is seen that as the seal strictness increase, temperature increase and the life cycle decreases. Strictness values bigger than $105 \mu \mathrm{m}$ do not affect the life cycle significantly.

\section{FINITE ELEMENT ANALYSIS (FEA)}

Two different basic material model is available for composing FEA model for elastomers. One of them is Rivlin Series (a polynomial function) that depends on strain invariants and the other one is Ogden Form (a strain energy 
function) that depends on stretch ratios. These models are embedded in ANSYS; some of them are Neo-Hookean, Arruda-Boyce, Gent, Blatz-Ko, Mooney Rivlin, Yeoh, Ogden hyperelastic models [20].

The most commonly used one is Mooney-Rivlin Strain Energy Function for the elastomers non-lineer stress analysis [13].

Contact stress has been analysed and evaluated by ANSYS Workbench. There are 3 criteria to make a FEA model of an elastomer material [21];

1. Model must be not linear,

2. Mechanical behaviour must be not linear,

3. Contact type that used in FEA software must be not linear.

According to these 3 criteria; non-linear model is chosen. Some presuppositions are;

1. Material is perfectly elastic,

2. Material is izotropic,

3. Material is uncompressible. According to these assumptions; hyperelastic model is choosen.

These criteria and pre-suppositions are also our boundry conditions.

Table 10. Mesh Form Analysis

\begin{tabular}{ccccccc}
\hline \multicolumn{7}{c}{ Different Mesh Forms Models } \\
\hline Mesh & 1 & 2 & 3 & 4 & 5 & 6 \\
$\begin{array}{c}\text { Number } \\
\text { Mesh }\end{array}$ & 202 & 525 & 2122 & 12562 & 49700 & 197955 \\
$\begin{array}{c}\text { Quality (\%) } \\
\text { Mesh }\end{array}$ & 92,7 & 96,8 & 98,2 & 98,6 & 98,9 & 98,91 \\
$\begin{array}{c}\text { Dimension } \\
\text { (mm.) }\end{array}$ & default & 0,05 & 0,025 & 0,01 & 0,005 & 0,0025 \\
\hline
\end{tabular}

Six different mesh models are composed as seen in table 10 , results of each is given in table 11.

The solution time for 4 th model is 739 s., for 5th model is $3990 \mathrm{~s}$. and for 6th model is $33624 \mathrm{~s}$. After making an evaulation according to the solution times and practical process, 5th model is chosen for ANSYS. 5th model has a low contact penetration as $0,4 \mu \mathrm{m}$ and this is acceptable for the FEA. Mesh form is seen in figure 20 for $160 \mu \mathrm{m}$ cover strictness sample.

Table 11. Mesh Form Analysis Results

\begin{tabular}{|c|c|c|c|c|c|c|c|}
\hline \multirow{2}{*}{ Model No. } & \multirow{2}{*}{ Max. Stress [MPa] } & \multirow{2}{*}{ Max. Strain } & \multirow{2}{*}{$\begin{array}{c}\text { Max. Contact } \\
\text { Pressure [MPa] }\end{array}$} & \multicolumn{3}{|c|}{ Contact Reaction Force [N] } & \multirow{2}{*}{$\begin{array}{c}\text { Contact } \\
\text { Penetration }[\mu \mathrm{m}]\end{array}$} \\
\hline & & & & & $Y$ & Total & \\
\hline 1 & 1,1586 & 0,10858 & 0,3912 & 4,165 & 0,6974 & 4,2232 & 7,5306 \\
\hline 2 & 1,2025 & 0,11159 & 0,4651 & 4,216 & 0,7102 & 4,275 & 4,0786 \\
\hline 3 & 1,3076 & 0,11904 & 0,6116 & 4,232 & 0,7073 & 4,2952 & 2,055 \\
\hline 4 & 1,471 & 0,13096 & 1,0506 & 4,318 & 0,6403 & 4,3647 & 0,8929 \\
\hline 5 & 1,5273 & 0,13496 & 1,5408 & 4,303 & 0,65692 & 4,3532 & 0,4003 \\
\hline 6 & 1,5568 & 0,13704 & 1,7655 & 4,308 & 0,65798 & 4,3575 & 0,2179 \\
\hline
\end{tabular}

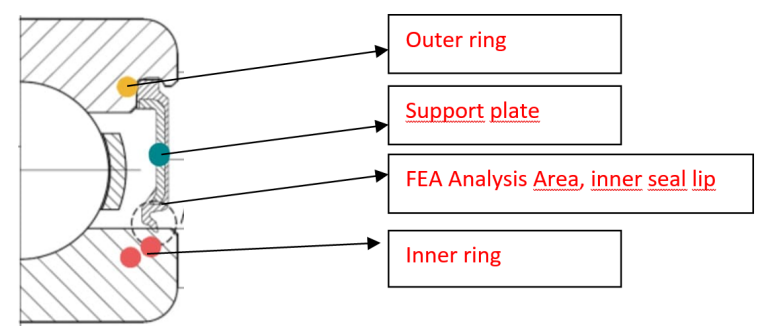

Figure 22. FEA Analysis Area

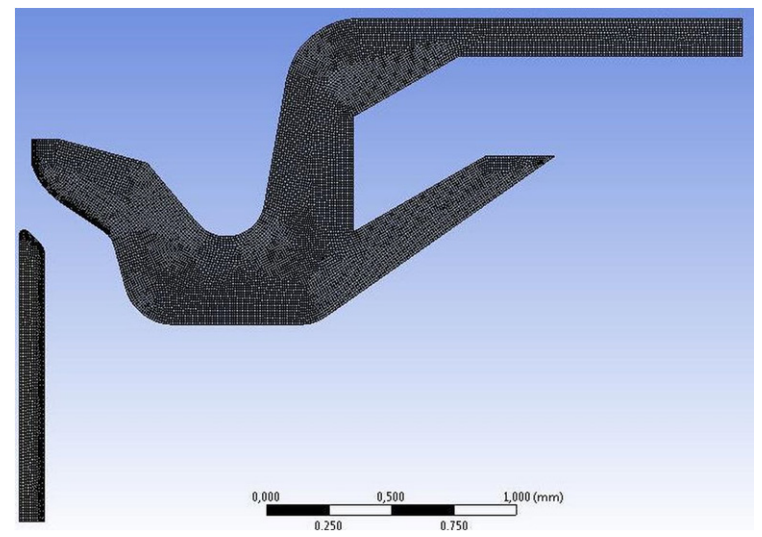

Figure 23. $160 \mu \mathrm{m}$ cover strictness mesh structure

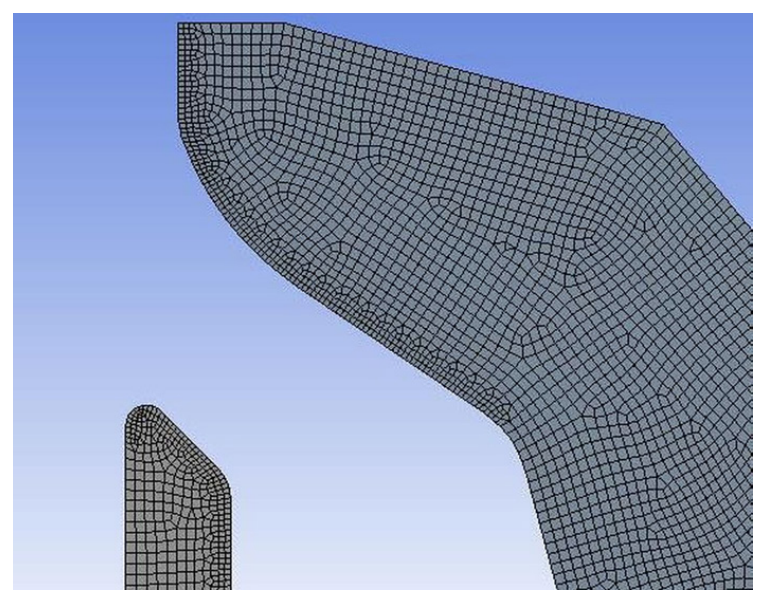

Figure 24. $160 \mu \mathrm{m}$ cover strictness mesh structure-detailed

Boundry Conditions are detailed as follows: Inner ring is fixed in all directions, elastomer seal has a displacement degree of freedom in $\mathrm{x}: 0 \mathrm{~mm}, \mathrm{y}:-0,75 \mathrm{~mm}$. Except FEA analysis area (between inner lip of elastomer seal and inner ring contact surface) Fig. 22, all the parts are fixed. Because, friction occurs in FEA analysis area. Our study/investigation is on seal strictness and friction force. 


\section{Hyperelastic Models in ANSYS}

Mooney -Rivlin Method, 9 parameter (Fig. 25) is chosen to solve curve fit method (Fig. 26.) in ANSYS.

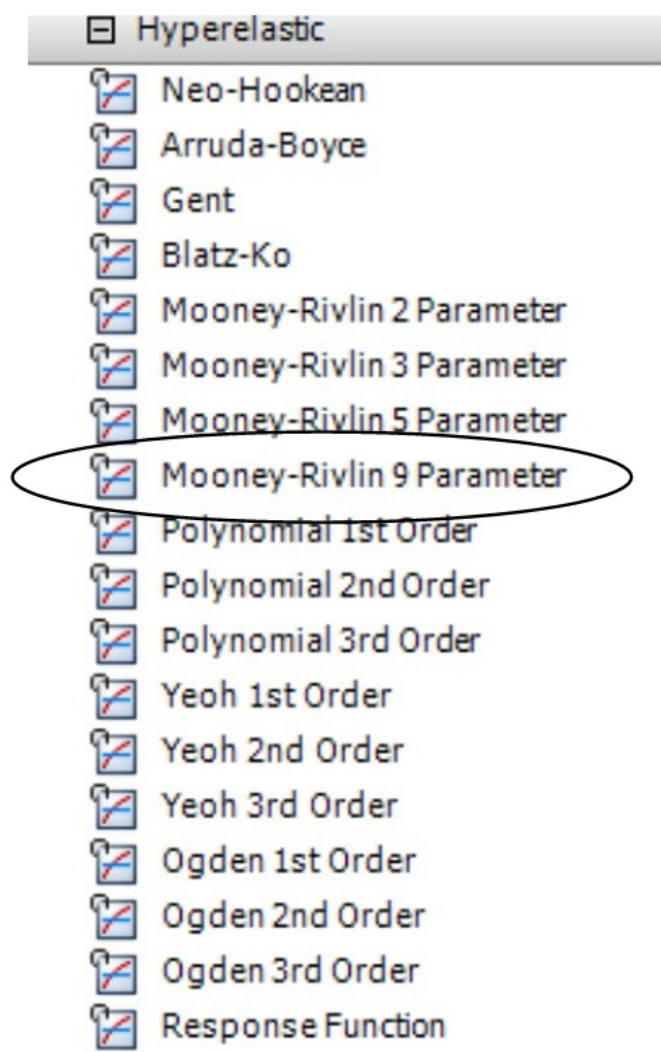

Figure 25. Hyperelastic Material Models in ANSYS Workbench

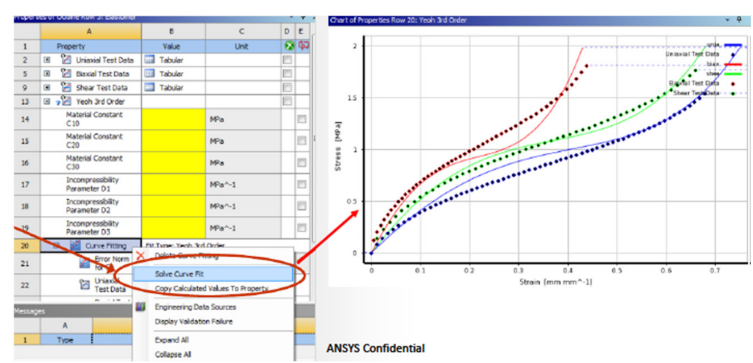

Figure 26. Solve Curve Fit Method by ANSYS Workbench [22]

\section{ANSYS Analysis Results}

Contact force in $200 \mu \mathrm{m}$ cover strictness is shown in Fig. 28. Most of the contact force is at $\mathrm{x}$-axis. As the seal strictness value increases, the contact force increases as shown in table 12.

Table 12. Contact Reaction Force between Seal and Bearing Slice (FEA Results)

\begin{tabular}{ccc}
\hline $\begin{array}{c}\text { Cover } \\
\text { Strictness } \\
{[\mu \mathrm{m} .]}\end{array}$ & $\begin{array}{c}\text { Rate of Friction Test Mean } \\
\text { Results }[\mathrm{Nm} .]\end{array}$ & $\begin{array}{c}\text { Rate of FEA Contact Force } \\
\text { Results }[\mathrm{Nm} .]\end{array}$ \\
\hline $105 / 45$ & $0,0755 / 0,0487=1,55$ & $3,10 / 1,53=2,02$ \\
$160 / 105$ & $0,1056 / 0,0755=1,40$ & $4,36 / 3,10=1,41$ \\
$200 / 160$ & $0,1314 / 0,1056=1,24$ & $5,18 / 4,36=1,18$ \\
\hline
\end{tabular}

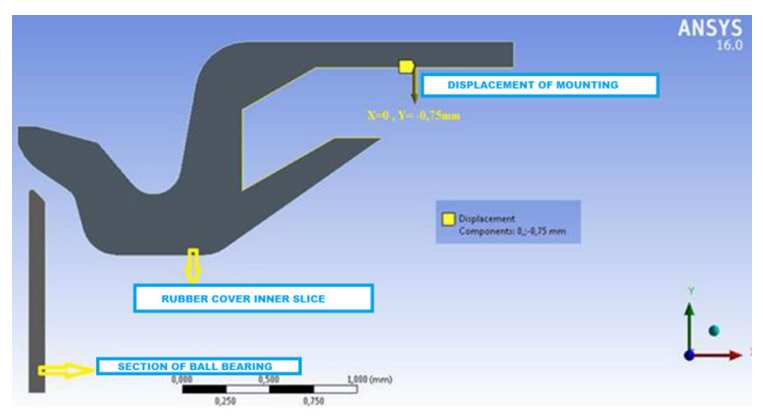

(a)

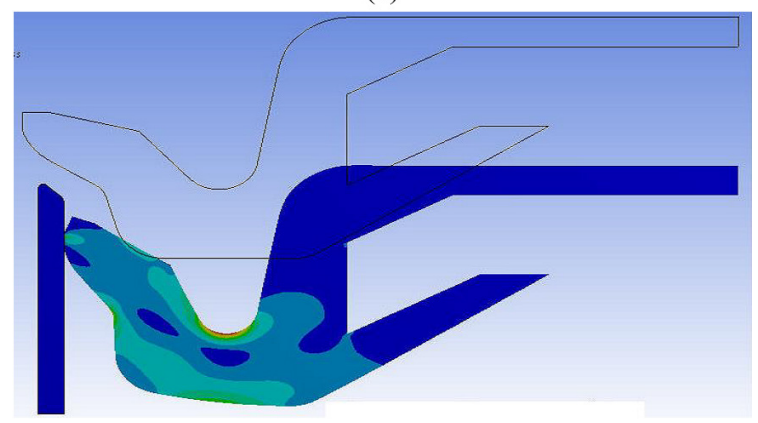

(b)

Figure 27. $160 \mu \mathrm{m}$ cover strictness ; position a) before mounting and b) during the mounting (stress distribution)

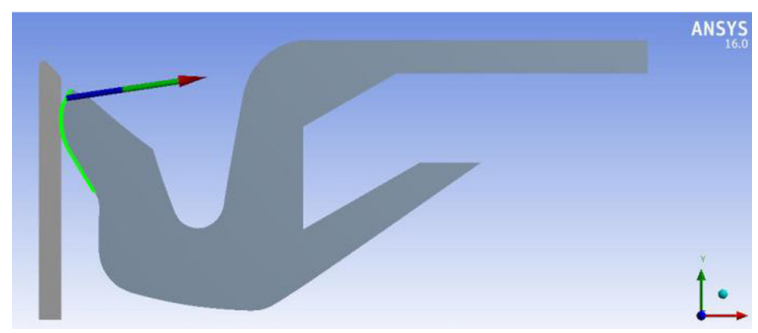

Figure 28. Total contact reaction force in $200 \mu \mathrm{m}$ cover strictness $(45,105$ and $160 \mu \mathrm{m}$ cover strictness is not shown, since they are same as $200 \mu \mathrm{m})$

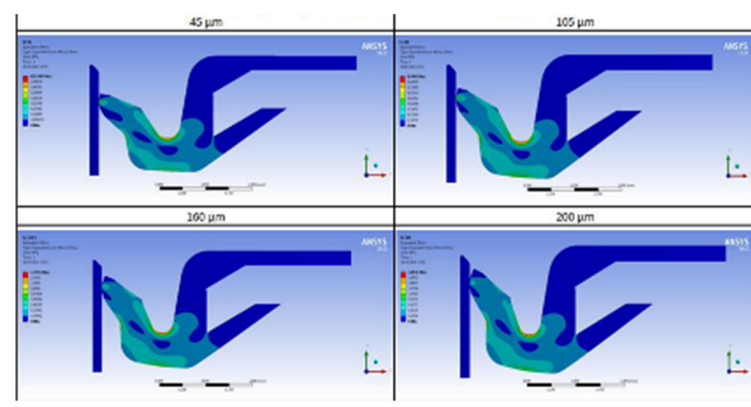

Figure 29. Contact Reaction Force for Different Seal Strictness Covers between Seal and Bearing Slice

Table 13. Comparison (By Ratio) of Friction Tests and FEA Results

\begin{tabular}{ccccc}
\hline \multirow{2}{*}{$\begin{array}{c}\text { Cover Strictness } \\
{[\mu \mathrm{m} .]}\end{array}$} & $\begin{array}{c}\text { Max. Equivalent } \\
\text { Stress [MPa] }\end{array}$ & \multicolumn{3}{c}{ Contact Reaction Force [MPa] } \\
\cline { 3 - 5 } 45 & 0,538 & 1,514 & 0,227 & 1,531 \\
105 & 0,949 & 3,074 & 0,461 & 3,108 \\
160 & 1,476 & 4,317 & 0,648 & 4,366 \\
200 & 1,853 & 5,13 & 0,77 & 5,187 \\
\hline
\end{tabular}




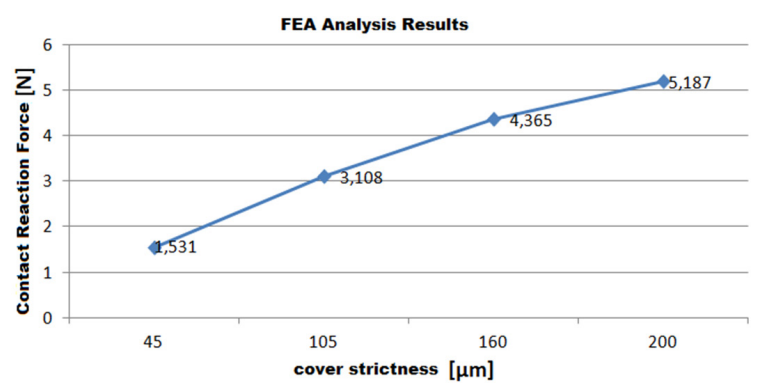

Figure 30. Contact Reaction Force between Seal and Bearing Slice (FEA Results)

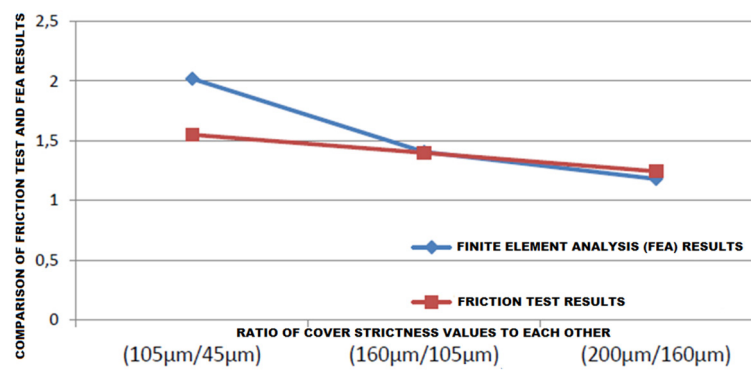

Figure 31. Friction Test and FEA Results (non-unit comparison)

As seen in Fig. 30, contact force increases with the high cover strictness values. The friction momnet test results and FEA-ANSYS analysis results are consistent with each other (table 13 and Fig. 31).

Friction test and FEA analysis results are consistent with each other as seen in Fig. 31.

\section{DISCUSSION}

One of the most significant parameters that affect the ball bearing performance is seal strictness and its design. As the test results are observed and examined, the temperature reaches $150^{\circ} \mathrm{C}$ at the $200 \mu \mathrm{m}$ seal strictness. This is a high value and is needed to be reevaluated. Namely; material (NBR) starts to deteriorate and lose its performance specifications at $150^{\circ} \mathrm{C}$. Sealing property is about to be lost in a short time. The most efficient temperature value should be in the $120-125^{\circ} \mathrm{C}$ range. So; a ball bearing seal strictness is a factor directly affect the life of a ball bearing.

Then it is essential to make optimization. We will choose either a lesser seal strictness value or a more durable material. More durable material means a more expensive material.

As the strictness increases, friction moment increases linearly at unloaded ball bearings. In our study, the effect of strictness affects directly the performance of ball bearing via friction moment and temperature degrees.
An optimum value for seal strictness according to the usage area is to be chosen.

The relationship between numerical results obtained from numeric simulation and friction moment test results have been analysed and evaulated. As a consequence, it has been observed and proved that the numeric results are consistent with the test results.

\section{CONCLUSION}

Based on the obtained results, the following deductions may be drawn;

1. The seal strictness has a great effect on the life of a rolling bearing.

2. As the strictness increases, temperature increases and this leads to a decrease in the life cycle of the bearing.

3. It should be made an optimization to choose the seal according to the usage area. Because there is a contradiction, if we choose strictness greater, we can provide the seal better, but the life cycle decreases as the temperature increases. Vice versa is also true.

4. These results are also consistent with theory and MESYS software.

5. The friction test and FEA/ANSYS results are consistent with each other.

6. The optimum service temperature of rolling bearing according to tests is $110^{\circ} \mathrm{C}$, because every temperature increase after $110^{\circ} \mathrm{C}$ decreases developed bearing life dramatically.

\section{ACKNOW LEDGEMENTS}

We are very grateful to the Ortadoğu Rulman Sanayi A.Ş. for helping and guiding us at conducting tests and making time for experiments; esp. Mr. Tahir YILDIRIM Manufacture Director, Mr. Bilal DEMİR Automotive Application Chief, Mr. Tahir YILDIRIM and Mr. İbrahim TEMİZBAŞ senior engineers.

\section{CONFLICT OF INTEREST}

Authors approve that to the best of their knowledge, there is not any conflict of interest or common interest with an institution/organization or a person that may affect the review process of the paper.

\section{AUTHOR CONTRIBUTION}

Z. Ozdemir, K. Sarigoz and O.S. Turkbas contributed equally this study and experiments. All authors take the access and responsibility for the integrity of data. 


\section{References}

1. Shigley's Mechanical Engineering Design, Eighth Edition Budynas $\$$ Nisbett. 2011.

2. ORS Rulman. Ortadoğu Rulman Sanayi ve Ticaret A.Ş. URL:https:// ors.com.tr/tr/page/42/rulman-nedir last update, 2017-12-19.

3. Harris, T. A., Kotzalas M. N., Essential Concepts of Bearing Technology, CRC Press, Taylor Francis Group, 2007.

4. Sada, T. Loss reduction of rolling bearings for the automobile, Journal of Japanese Society of Tribologists. (2017).

5. Gorycki, L. Analysis of the Impact of the Cage Type on the Frictional Moment Rolling Bearings, David Publishing. Journal of Mechanics Engineering and Automation 5 (2015) 450-453.

6. B.Choe, J.Lee, D.Jeon and Y.Lee, Experimental study on dynamic behavior of ball bearing cage in cryogenic environments, Part I: Effects of cage guidance and pocket clearances. Mechanical Systems and Signal Processing Elsevier (2018).

7. Y.Cui, S.Deng, R.Niu, G.Chen, Vibration effect analysis of ball dynamic unbalance on the cage of high-speed cylindrical ball bearing. Journal of Sound and Vibration Elsevier (2018)

8. Z.Yang, T.Yu, Y.Zhang and Z.Sun, Influence of Cage Clearance on the Heating Characteristics of High-Speed Ball Bearings. Tribology International (2016).

9. Takimoto, M., Ishikawa, T., and Harada, K., Technical development of automotive wheel bearing seals (Muddywater resistant seal, low-temperature environment seal and super low-torque seal). JTEK Engineering Journal (2011) 64-68.

10. White J. R., De, S. K., Rubber Technologist's Handbook, The United Kingdom. Rapra Technology Limited, 50, 77-78, 2001.
11. SKF Group, Rolling Bearings Catalogue, 2013.

12. Brown R., Physical Testing of Rubber. Springer, 2006.

13. Gent, A. N. Engineering With Rubber How to Design Rubber Components (Third Edition), Munich: Hanser Publishers, 2012.

14. Simpson, R. B. "Rubber Basics", United Kingdom: Rapra Technology Limited, 2002.

15. ASTM G182 - 13, Standard Test Method for Determination of the Breakaway Friction Characteristics of Rolling Element Bearings, 2018.

16. DIN 51819-1 2016 Edition, Testing of Lubricants Mechanical-Dynamic Testing In The Roller Bearing Test Apparatus FE8 - Part 1: General Working Principles, 2016.

17. ISO-16281:2008. Rolling bearings-Methods for calculating the modified reference rating life for universally loaded bearing, 2008.

18. ISO-281:2007. Rolling Bearings - Dynamic Load Ratings and Rating Life, International Standard Organization, 11-12, $18,25-32,44,2010$.

19. ISO 16281:2008-Rolling bearings: Methods for calculating the modified reference rating life for universally loaded bearing, 2008.

20. MESYS Software MSC Software. Nonlinear finite element analysis of elastomers. MSC Software, 2010.

21. Ghaemi, H., Behdinan, K., Spence, A. On the development of compressible pseudo-strain energy density for elastomer application to finite element. Journal of Materials Processing Technology, 318. (2006).

22. Carlescu, V., Prisacaru, G., Olaru, N. D. (2014). FEM simulation on uniaxial tension of hyperelastic elastomers. Applied Mechanics and Materials 659 (2014), 57-62.

23. Miller, K. (2014). Experiments and fitting of advanced polymer models in ANSYS. Axel Products Regional Conference, 28, 2014. 